\title{
Age-Related Changes in the Immunohistochemical Localization of Inducible Nitric Oxide Synthase (iNOS) and Nuclear Factor-kappa B (NF- $\kappa$ B) in the Mouse Cochlea
}

\author{
Masaru Kimura ${ }^{1}$, Men-dar $\mathrm{Wu}^{2}$, Shigeru Inafuku ${ }^{2}$ and Hiromichi Ishigami ${ }^{2}$ \\ ${ }^{1}$ Department of Anatomy, Aichi Medical University, Nagakute-cho, Yazako, Aichi-gun, Aichi 480-1103 and \\ ${ }^{2}$ Department of Otorhinolaryngology, Aichi Medical University, Nagakute-cho, Yazako, Aichi-gun, \\ Aichi 480-1103
}

Received for publication October 2, 1998 and in revised form November 12, 1998

Localization of iNOS and NF- $\kappa$ B in the cochlear tissues of ddy-strain mice was studied immunohistochemically with reference to ageing. Severe structural disorders with a decrease in the number of cells were found, especially in the organ of Corti and in the spiral ganglion of older mice. Throughout all age-spans studied, iNOS-like immunoreactivity was found in the cells of Hensen, Claudius and the outer spiral sulcus epithelium, and it increased dramatically with age. A very small number of cells in the stroma of the spiral ligament and spiral limbus of younger mice up to 12 months of age showed weak
iNOS immunoreactivity, while the spiral ganglion cells of the younger mice were almost negative. In mice after 18 months of age, however, strong iNOS immunoreactive cells remarkably increased in the spiral ligament and spiral limbus. Moreover, spiral ganglion neurons that survived from age-related cell death also showed strong reactivity. The immunohistochemical localization of NF- $k$ B and its change with age were nearly the same as those of iNOS. The possible roles of iNOS and NF- $\kappa B$ in the changes of mouse cochlear tissues with advancing age were discussed.

Key words: Mouse cochlea, iNOS, NF- $\kappa$ B, Aging, Immunohistochemistry

\section{Introduction}

Nitric oxide (NO) is known to participate in physiological and pathophysiological processes, including neurotransmission [6], regulation of blood flow [17, 22], and cell injury in a variety of tissues and organs [3, 4]. In biological processes, NO is produced by nitric oxide synthases, which catalyze L-arginine into NO and L-citrulline with some cofactors $[17,19]$. Three isozymes of nitric oxide synthase (NOS) have been reported. Since two of them are constitutively expressed in the endothelium of blood vessels and brain tissues or other neuronal tissues, they are called constitutive NOS (cNOS) and are regulated in their activity depending on intracellular $\mathrm{Ca}^{++}$through the function of calmodulin $[1,2]$. The other type of NOS is expressed only after transcriptional induction by

Selected by "The 10th International Congress of Histochemistry and Cytochemistry" held in Kyoto, Japan on Aug. 18-23, 1996.

Correspondence to: Dr. Masaru Kimura, Department of Anatomy, Aichi Medical University, Nagakute-cho, Yazako, Aichi-gun, Aichi 480-1103, Japan. cytokines and/or bacterial lipopolysaccharides via the activation of transcription factors including nuclear factor kappa B (NF- $\kappa \mathrm{B})[26,27]$, and is therefore called inducible NOS (iNOS). Once expressed, iNOS catalyzes the production of NO in higher amounts and more persistently than constitutive NOSs [15]. It is known that a high concentration of persistently produced NO by iNOS exerts toxic effects on living cells [26]. In this regard, we took an interest in the age-related rise or fall of NOSs, especially iNOS in the cochlear organ with respect to age-related hearing loss, because it is known that hair cells and spiral ganglion cells decrease in number with advancing age [9, $11,12]$. The present study, therefore, was designed to determine the age-related changes in the immunohistochemical localization of iNOS and NF- $\kappa$ B in the cochlear tissues.

\section{Materials and Methods}

Tissue preparation

Male ddy-strain mice aged 1, 3, 6, 12, 18, and 24 months were maintained under specific-pathogen free 
conditions until they were sacrificed. After measurement of auditory brainstem response (ABR) thresholds of mice were measured to determine hearing abilities by the usual method employed in our laboratory [12], i.e., cochlear organs were fixed by transcardial perfusion of a fixative containing 3\% paraformaldehyde (PFA) and 1\% glutaraldehyde (GA) in $0.1 \mathrm{M}$ phosphate buffer (PB) at $\mathrm{pH} 7.4$ for 5 to $10 \mathrm{~min}$ at room temperature. Cochlear organs were removed and then decalcified with 7\% EDTA in a refrigerator for 2 days, and embedded in paraffin according to a conventional method. The paraffin sections were cut serially at 3- to $4-\mu \mathrm{m}$ thick along the midmodiolar plane. Three from each of 30 serial sections were used for a haematoxylin and eosin ( $\mathrm{H} \& \mathrm{E})$ stain and immunohistochemical stains for iNOS and NF- $\kappa$ B.

\section{Immunohistochemical staining}

Immunohistochemical staining was performed as described previously [25]. In brief, deparaffinized sections were pretreated with $3 \%$ hydrogen peroxide for $10 \mathrm{~min}$ to inhibit intrinsic peroxidases followed by incubation in diluted normal goat serum (10\%) in PBS to block nonspecific binding. The sections were immersed in the first antibodies diluted 500 to 1,000 times for $1 \mathrm{hr}$ at room temperature (RT). The localization of antigens was finally visualized by diaminobenzidine reaction using SABC (streptavidin-biotin complex) method. Counter staining of nuclei with haematoxylin was performed when needed. Some cochlear sections were stained for confocal laser scanning microscopy (CLSM) using a fluorescent dye (Cydye: Amersham Pharmacia Biotech Ltd., Bucks, U.K.). A confocal laser scanning microscope (LSMGB200: Olympus, Co., Ltd., Tokyo) was used for CLSM. Affinity-purified polyclonal anti-iNOS antibodies (obtained from rabbits immunized with a synthetic peptide composed of 14 amino acids corresponding to the Cterminal end of mouse macrophage iNOS) were purchased from Affinity BioReagents Co., Ltd., New Jersey. As to the anti-NF- $\kappa \mathrm{B}$ antibody, two kinds of affinity-purified rabbit polyclonal antibodies against $\mathrm{NF}-\kappa \mathrm{Bp} 50(50 \mathrm{kDa}$ subunit of NF- $\kappa \mathrm{B}$ complex) and NF- $\kappa \mathrm{Bp} 65$ (65 kDa subunit) were purchased from Santa Cruz Biotechnology Inc., California. The data for these antibodies are summarized in Table 1.

\section{Results}

\section{Light microscopic structure of the cochleae}

The animals used in this study showed ABR thresholds nearly the same as those described in our previous report [25]. In young animals up to 12 months of age (their ABR thresholds were in a nearly normal range, e.g., 10 to $24 \mathrm{dBnHL}$ ), no abnormal structural changes such as degeneration and loss of cells in the cochlear duct tissues and the spiral ganglions (SGs) were found (Fig. 1), whereas mice after 18 months old (their ABR thresholds were much higher than the normal level, e.g., more than 70 $\mathrm{dBnHL}$ ) showed severe morphological disintegration, especially in the organ of the Corti and SGs. Hair cells, their supporting cells, and even pillar cells in the organ of Corti in 24-month-old mice were hardly distinguishable, and spiral ganglion neurons had severely decreased in number (Fig. 2). In addition, structural disorder of the spiral prominence, mesh-like changes in the spiral ligament, especially just below the outer spiral sulcus without its epithelium, and a decrease in the thickness of the stria vascularis lacking distinguishable intraepithelial capillaries were observed (Fig. 2).

\section{Immunohistochemical findings}

The immunohistochemical reactivities in cochlear tissues fixed with a perfusion of the aldehyde mixture, decalcified with EDTA, and without any pretreatment of sections prior to immunohistochemical incubation were so clearly detectable that the immunohistochemical data for cochlear tissues described here are mainly obtained from sections of cochlear tissues without any pretreatment. Our previous report also showed that aldehyde-fixed-, EDTA-decalcified-, and paraffin-embedded cochlear tissues sufficiently preserved the immunohistochemical reactivity for NOSs [25].

As summarized in Tables 2 and 3, the cells showing iNOS immunoreactivity throughout all age spans of mice used were those of Hensen, Claudius, and the outer sulcus epithelium (Figs. 3, 4). The reactivity became stronger with age. A few weakly positive cells were sometimes found in the stroma of the spiral ligament and the spiral limbus in young animals up to 12 months of age (Fig. 3). The reactivity and the number of positive cells in these

Table 1. Antibodies and specificity

\begin{tabular}{llll}
\hline \multicolumn{1}{c}{ Antibodies } & \multicolumn{1}{c}{ Specificity } & \multicolumn{1}{c}{ Dilution } & \multicolumn{1}{c}{ Source } \\
\hline [First-step polyclonal antibodies] & & & \\
anti-iNOS & Mouse macrophage iNOS & $1: 500$ to $1: 1,000$ & AffintyBioreagent (USA) \\
anti-NF- $\kappa$ Bp50 & Human NF- $\kappa$ Bp50 & $1: 1,000$ & Santa Cruz (USA) \\
anti-NF- $\kappa$ Bp65 & Human NF- $\kappa$ Bp65 & $1: 1,000$ & Santa Cruz (USA)
\end{tabular}

[Second-step polyclonal antibodiy] anti-rabbit IgG biotin conjugate 

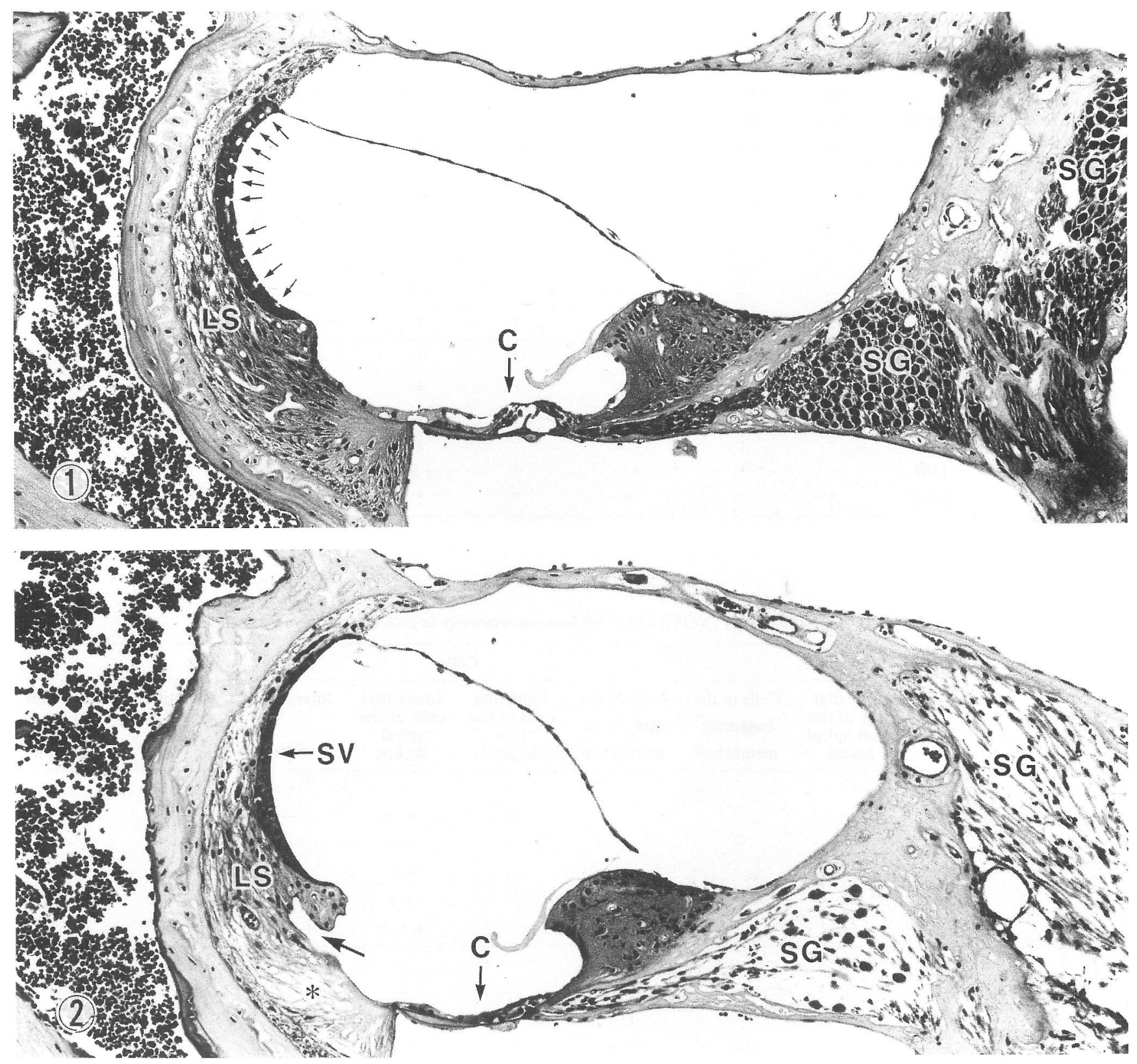

Fig. 1. The cochlear duct and neighboring tissues taken from a 3-month-old mouse. Haematoxylin and eosin stain. The structural characteristics of the organ of Corti (C) were well preserved. Circular or oblique empty spots found in the stria vascularis are lumina of the intraepithelial capillary (arrows). SG, the spiral ganglion; LS, the spiral ligament. $\times 165$.

Fig. 2. The cochlear duct and neighboring tissues of a 24-month-old mouse. Haematoxylin and eosin stain. The organization of the organ of Corti (C) is severely disintegrated so that its original particular structure is hardly seen, but some cells still remain on the basement membrane. In the somewhat shrunken and thinned stria vascularis (SV) the intraepithelial capillaries are not found (compare with those in Fig. 1). A deep furrow (see arrow) is found in the spiral prominence without its surface covering cells. A mesh-like structure is seen in a part of the spiral ligament (asterisk) because of stroma cell loss. A great decrease in the number of cells is also found in the spiral ganglions (SG) so that their intracellular space is considerably widened. $\times 165$.

sites increased remarkably after 18 months of age (Fig. 4). However, mitotic figures of the nuclei could not be found. Although, iNOS immunoreactivity in the SGs up to 12 months of age was completely negative (Fig. 7), strong reactivity appeared in neurons after 18 months of age (Figs. 8, 9). As to the NF- $\kappa$ B immunohistochemistry, the data shown here were mainly obtained by using the antibodies against NF- $\kappa$ Bp50 subunits because they reacted better for unknown reasons than those for NF- $\kappa \mathrm{Bp} 65$ subunits. The NF- $\kappa \mathrm{B}$ reactivity was almost parallel to that of iNOS (Figs. 5, 6, 10-11; Tables 2 and 3). Although the reaction products for $\mathrm{NF}-\kappa \mathrm{B}$ were usually found in the 
Table 2. Age changes of $i N O S$ and NF- $\kappa B$ immunoreactivity in cells of the cochelar duct

\begin{tabular}{|c|c|c|c|c|c|c|c|c|c|}
\hline \multirow[b]{2}{*}{ Substances } & \multirow[b]{2}{*}{ Months } & \multicolumn{8}{|c|}{ Cells } \\
\hline & & $\begin{array}{l}\text { Inner } \\
\text { hair } \\
\text { cells }\end{array}$ & $\begin{array}{l}\text { Outer } \\
\text { hair } \\
\text { cells }\end{array}$ & $\begin{array}{c}\text { Inner } \\
\text { supporting } \\
\text { cells }\end{array}$ & $\begin{array}{l}\text { Pillar } \\
\text { cells }\end{array}$ & $\begin{array}{l}\text { Deiters } \\
\text { cells }\end{array}$ & $\begin{array}{c}\text { Hensen } \\
\text { cells }\end{array}$ & $\begin{array}{l}\text { Claudius } \\
\text { cells }\end{array}$ & $\begin{array}{l}\text { Epithelial } \\
\text { cells of the } \\
\text { outer spiral } \\
\text { sulcus }\end{array}$ \\
\hline \multirow{6}{*}{ iNOS } & $1 \mathrm{M}$ & - & - & + & - & +- & + & + & + \\
\hline & $3 \mathrm{M}$ & - & - & +- & - & +- & ++ & ++ & ++ \\
\hline & $6 \mathrm{M}$ & - & - & +- & - & +- & + & + & + \\
\hline & $12 \mathrm{M}$ & - & - & +- & - & +- & + & + & + \\
\hline & $18 \mathrm{M}$ & - & - & +- & - & ++ & ++ & ++ & ++ \\
\hline & $24 \mathrm{M}$ & $?$ & $?$ & $?$ & $?$ & $?$ & +++ & +++ & +++ \\
\hline \multirow{6}{*}{$N F-\kappa B$} & $1 \mathrm{M}$ & - & - & +- & - & + & + & + & + \\
\hline & $3 \mathrm{M}$ & - & - & +- & - & + & ++ & ++ & ++ \\
\hline & $6 \mathrm{M}$ & - & - & +- & - & + & ++ & ++ & ++ \\
\hline & $12 \mathrm{M}$ & - & - & +- & - & + & ++ & ++ & ++ \\
\hline & $18 \mathrm{M}$ & - & - & +- & - & ++ & +++ & +++ & ++ \\
\hline & $24 \mathrm{M}$ & $?$ & $?$ & $?$ & $?$ & $?$ & +++ & +++ & +++ \\
\hline
\end{tabular}

- : negative; +- : doubtfully positive; + : weakly positive; ++ : intermediately positive; +++ : strongly positive

Table 3. Age changes of iNOS and NF- $\kappa B$ immunoreactivity in cells of the cochlear tissues

\begin{tabular}{|c|c|c|c|c|c|c|c|c|c|}
\hline \multirow[b]{2}{*}{ Substances } & \multirow[b]{2}{*}{ Months } & \multicolumn{8}{|c|}{ Cells } \\
\hline & & $\begin{array}{l}\text { Epithelial } \\
\text { cells of the } \\
\text { inner spiral } \\
\text { sulcus }\end{array}$ & $\begin{array}{l}\text { Cells in the } \\
\text { basement } \\
\text { membrane }\end{array}$ & $\begin{array}{l}\text { Cells of the } \\
\text { Reissner's } \\
\text { membrane }\end{array}$ & $\begin{array}{l}\text { Epithelial } \\
\text { cells of the } \\
\text { stria } \\
\text { vascularis }\end{array}$ & $\begin{array}{l}\text { Interstitial } \\
\text { cells of the } \\
\text { spiral } \\
\text { limbus }\end{array}$ & $\begin{array}{c}\text { Interdental } \\
\text { cells }\end{array}$ & $\begin{array}{l}\text { Interstitial } \\
\text { cells of the } \\
\text { spiral } \\
\text { ligament }\end{array}$ & $\begin{array}{l}\text { Nerve cells } \\
\text { of the } \\
\text { spiral } \\
\text { ganglion }\end{array}$ \\
\hline \multirow{6}{*}{ iNOS } & $1 \mathrm{M}$ & - & - & - & - & - & - & ++ & - \\
\hline & $3 \mathrm{M}$ & - & - & - & - & +- & - & + & - \\
\hline & $6 \mathrm{M}$ & - & - & - & - & +- & - & + & - \\
\hline & $12 \mathrm{M}$ & +- & - & - & - & +- & +- & + & - \\
\hline & $18 \mathrm{M}$ & +- & - & +- & - & ++ & ++ & ++ & ++ \\
\hline & $24 \mathrm{M}$ & - & - & +- & - & +++ & +++ & +++ & +++ \\
\hline \multirow{6}{*}{$N F-\kappa B$} & $1 \mathrm{M}$ & - & - & +- & - & - & + & + & +- \\
\hline & $3 \mathrm{M}$ & - & - & +- & - & - & + & + & +- \\
\hline & $6 \mathrm{M}$ & - & - & +- & - & - & + & ++ & + \\
\hline & $12 \mathrm{M}$ & - & - & +- & - & +- & + & ++ & ++ \\
\hline & $18 \mathrm{M}$ & - & - & +- & - & ++ & + & ++ & +++ \\
\hline & $24 \mathrm{M}$ & - & - & +- & - & ++ & + & ++ & +++ \\
\hline
\end{tabular}

- : negative; +- : doubtfully positive: + : weakly positive; ++ : intermediately positive; +++ : strongly positive

cytoplasm of positive cells, some cells seemed to have the reaction products in their nucleus (Fig. 12). This could be confirmed by the detection of fluorescent signals emitted from a focal plane through the cell nucleus in CSLM (Fig. 12).

\section{Discussion}

As shown in our previous study [25], aldehydefixed, paraffin-embedded cochlear tissues clearly showed sufficient immunoreactivity to be observed. A plausible reason for this phenomenon seemed to be the effects of EDTA used for decalcification of the bone surrounding the tissues, since EDTA is more effective than citrate in the retrieval of some antigens [16].

In the present study, the structural disintegration of the organ of Corti and a decrease in the number of cells in SGs found in mice after 18 months of age strongly imply that degeneration followed by cell death must have occurred before they were lost, and the ABR threshold of older mice thereby greatly elevated. Furthermore, the fact that remarkable iNOS immunoreactivity was always found 


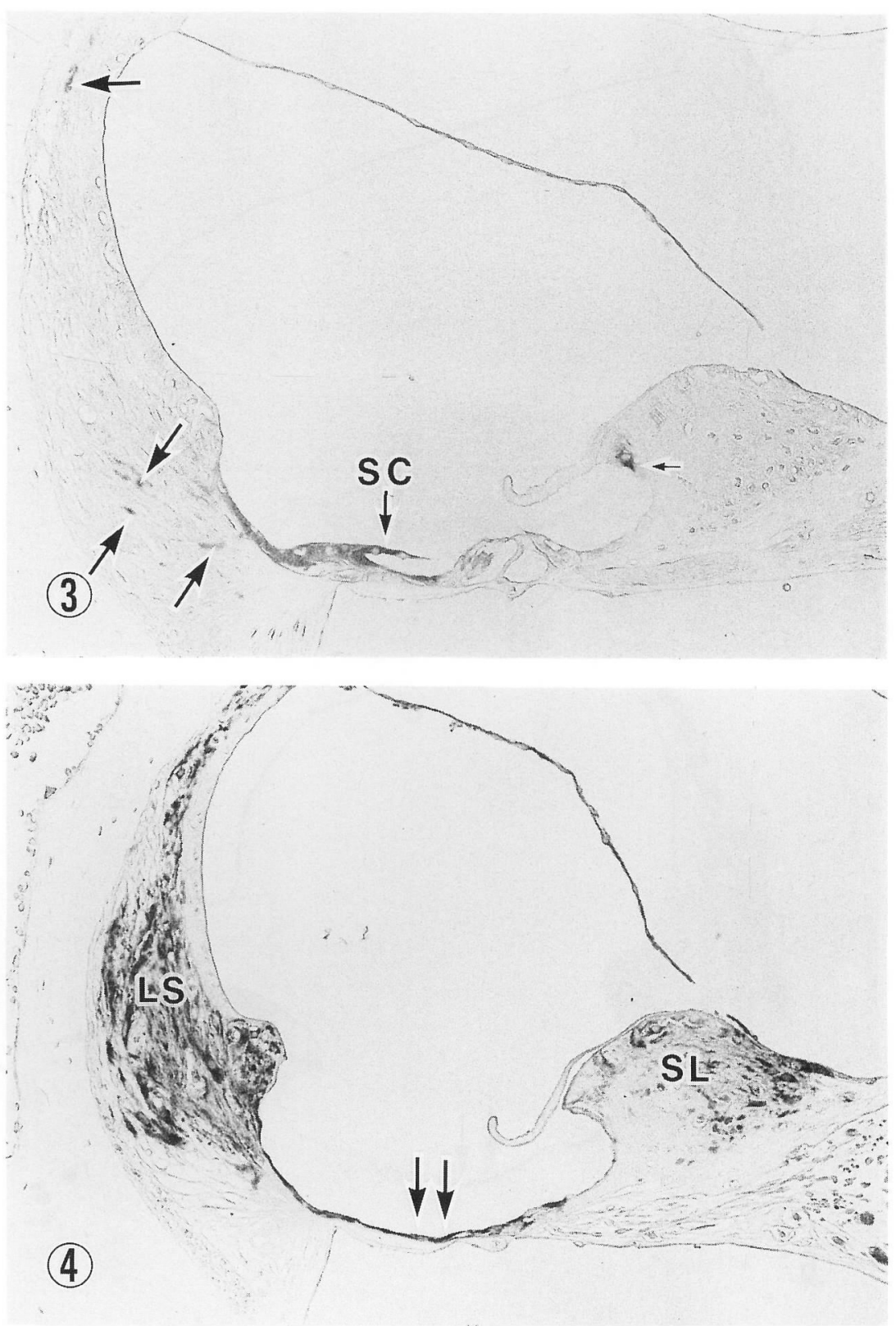

Fig. 3. The cochlear duct of a 3-month-old mouse stained with the iNOS antibody. The reaction products showing the localization of iNOS are mainly found in the cells of Hensen and Claudius (SC). Some of the cells in the spiral ligament (large arrows) and in the spiral limbus (a small arrow) also show reaction products. $\times 200$.

Fig. 4. The cochlear duct of a 24-month-old mouse stained with the same antibody as in Fig. 3. Numerous heavily stained stroma cells are seen in the spiral ligament (LS) and the spiral limbus (SL). The remaining cells on the luminal surface of the basement membrane (arrows) where the organ of Corti should be located in younger animals are also stained, $\times 200$.

in the cochlear tissues of 18 - and 24-month-old mice indicates a long-lasting expression of iNOS responsible for persistent NO production. As has been known, iNOS was first discovered as an enzyme producing NO involved in the immunological process of macrophages, and has also been considered to contribute to degeneration and cell death in a variety of tissues $[7,10,26]$ because of its high output of NO compared with the two constitutive NOSs [26]. In this regard, the great increase in iNOS immuno- histochemical reactivity and the considerably long-lasting expression of iNOS in cochlear tissues of senescent mice probably is related to the degeneration and consequent cell death in cochlear tissues. Meanwhile, a superoxide dismutase (SOD) is usually expressed in cochlear tissues of young adults [18] and is known to decrease in older animals [21]. An increase in superoxide radicals due to the decrease in SOD has been believed to be involved in animal aging [8]. Moreover, the idea that oxidative 


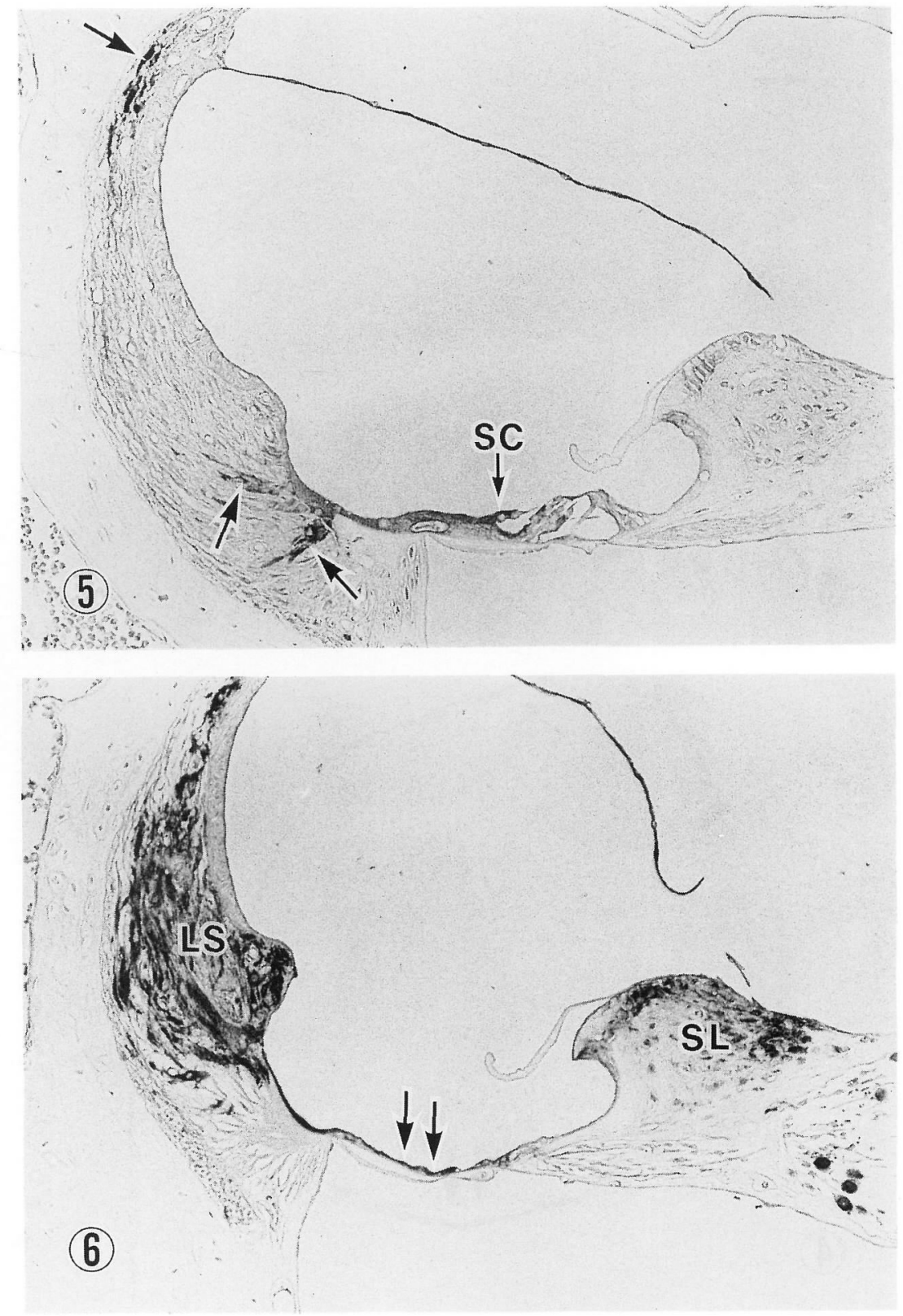

Fig. 5. The cochlear duct of a 3-month-old mouse stained with the antibody against the $50 \mathrm{kDa}$ subunit of NF- $\kappa \mathrm{B}$. The reaction products showing the localization of NF- $\kappa \mathrm{B}$ are mainly found in the cells of Hensen and Claudius (SC), and some stroma cells in the spiral ligament (arrows) are also positively stained. $\times 200$.

Fig. 6. The cochlear duct of a 24-month-old mouse stained with the same antibody as in Fig. 5. Most of the stroma cells in the spiral ligament (LS) and in the spiral limbus (SL) show a strong immunoreactivity for NF- $\kappa$ B. The remaining cells on the basement membrane as described in the caption of Fig. 4 are also stained (arrows). $\times 200$.

stresses play a causative role in iNOS expression in living cells [14] has been widely accepted by many investigators. Oxidative stress can also be a trigger for the activation of $N F-\kappa B$ [20]. NF- $\kappa B$ is known as one of the major transcription factors for iNOS expression by binding to the iNOS gene [27]. It also can be considered, therefore, that in the cochlear tissues of older mice the increased superoxide radicals due to the decrease in SOD with advancing age triggered the activation of $\mathrm{NF}-\kappa \mathrm{B}$, after which the activated NF- $\kappa \mathrm{B}$ stimulated iNOS expression. Moreover, an intrinsic or extrinsic NO introduced to tissues occasionally acts as a protective agent for tissues against oxidative stresses and ischemia-reperfusion injury of tissues [13, 24]. Even NO produced by iNOS expressed under inflammatory stimuli prevented tissue damage. This suggests that the expression of iNOS was a critical protective response to injury in tissue inflammation [23]. As a whole, in younger animals the iNOS expressed in 

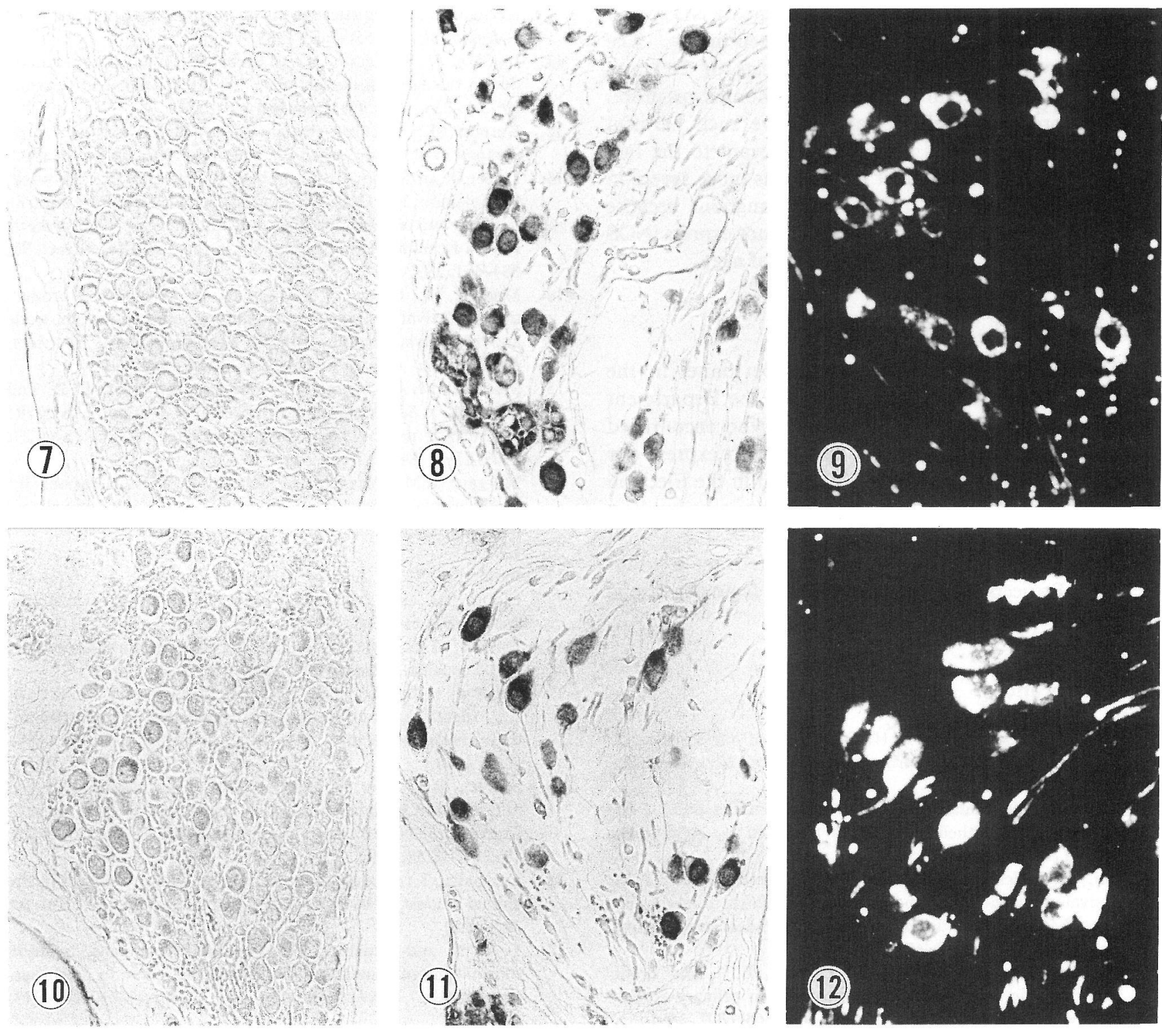

Fig. 7. The spiral ganglion of a 3-month-old mouse stained with the iNOS antibody. No reaction product is seen. $\times 400$.

Fig. 8. The spiral ganglion of a 24-month-old mouse stained with the same antibody as in Fig. 7. Most of the ganglion cells, which have survived the crisis of cell death due to aging, show strong immunoreactivity. $\times 400$.

Fig. 9. The localization of iNOS in the spiral ganglion of a 24-month-old mouse. This was selected from a series of pictures photographed by shifting the focus step-by-step at one micrometer intervals in CSLM. Note that the reaction products cannot be found in their nucleus surrounded by the cytoplasm with strong immunoreactivity. $\times 400$.

Fig. 10. The spiral ganglion of a 3-month-old mouse stained with a specific antibody against the 50-kDa subunit of NF- $\kappa \mathrm{B}$. No clearly visible immunoreactivity is found. $\times 400$.

Fig. 11. The spiral ganglion of a 24-month-cld mouse stained with the same antibody as in Fig. 10. Most of the ganglion cells are strongly stained, but the number of cells has severely decreased. $\times 400$.

Fig. 12. The localization of NF- $\kappa \mathrm{B}$ in the spiral ganglion of a 24-month-old mouse. Compared with the nuclei of ganglion cells found in Fig. 9 , the nuclei seen in this picture are clearly stained, and it is also clear that they do not overlap with their cytoplasmic portion because this photograph is selected from a series of pictures photographed in the same way as in Fig. 9.

the cells of Hensen, Claudius, and the outer spiral sulcus epithelium may produce NO to compensate for the physiological circumstances surrounding the organ of Corti with its capacity to reduce superoxide radicals and to stimulate guanylate cyclase. In older animals iNOS may be expressed in many cells of cochlear tissues to protect these cells, including hair cells, from harmful stimuli by superoxide radicals. Furthermore, even if iNOS has been expressed to take part in the protection of cells from increased superoxide radicals with age, if it were over- 
expressed and thus produced high amounts of NO over a loug period, it must then contribute to cell injury. The only cells resistant to the harmful effects of NO and oxidants could have survived until 24 months or more, since NO-producing cells usually survive such harmful effects by NO [5]. This is probably relevant to the fact that a decrease in the number of cells was more severe in the organ of Corti and in the spiral ganglion, because hair cells and spiral ganglion neurons did not express iNOS during their earlier stages ( $<12$ months of age).

\section{Acknowledgments}

The authors are indebted to all personnel in the Department of Otorhinolaryngology and the Department of Anatomy, Aichi Medical University, who encouraged us to complete this study. We also wish to express our thanks to Mr. Miyake and Mr. Nakagomi in the Electron Microscopy Division for their excellent assistant work in making the photographs for this report.

A part of this study was supported by a grant (Research Projects on Aging and Health) from the Ministry of Health and Welfare of Japan.

\section{References}

1. Bredt, D. S. and Snyder, S. H.: Isolation of nitric oxide synthetase, a calmodulin-requiring enzyme. Proc. Natl. Acad. Sci. USA 87; 682-685, 1990.

2. Busse, R. and Mulsch, A.: Calcium-dependent nitric oxide synthesis in endothelial cytosol is mediated by calmodulin. FEBS Lett. 265; 133-136, 1990.

3. Cui, S., Reichner, J. S., Mateo, R. B. and Albina, J. E.: Activated murine macrophages induce apoptosis in tumor cells through nitric oxide-dependent or -independent mechanisms. Cancer Res. 54; 2462-2467, 1994.

4. Dawson, V. L., Dawson, T. M., London, E. D. and Bredt, D. S.: Nitric oxide mediate neurotoxicity in primary cortical culture. Proc. Natl. Acad. Sci. USA 88; 6368-6371, 1991.

5. Dawson, V. L., Dawson, T. M., Bartley, D. A., Uhl, G. R. and Snyder, S. H.: Mechanism of nitric oxide-mediated neurotoxicity in primary cultures. J. Neurosci. 13; 2651-2661, 1993.

6. Garthwaite, J., Sarah, L., Charles, S. L. and Chess-Williams, R.: Endothelium-derived relaxing factor release on activation of NMDA receptors suggests role as intercellular messenger in the brain. Nature 336; 385-388, 1988.

7. Green, S. J., Meltzer, M. S., Hibbs, J. B. Jr. and Nacy, C. A.: Activated macrophages destroy intracellular Leishmania major amastigotes by a L-arginine-dependent killing mechanism. J. Immunol. 144; 278-283, 1990.

8. Harman, D.: Free radical theory of aging. In "Role of Free Radicals in the Organization and Evolution of Life, Aging, and Disease Process", ed. by J. E. Jhonson et al., Alan R. Liss, New York, 1986, pp. 3-49.

9. Henry, K. R., McGinn, M. D. and Chol, R. A.: Age-related auditory loss in the mongolian gerbil. Arch. Otorhinolaryngol. 228; 233-238, 1980.

10. Hibbs, J. B. Jr., Vavrin, Z. and Taintor, R. R.: L-arginine is required for expression of the activated macrophage effector mechanism causing selective metabolic inhibition in target cells. J. Immunol. 138; 550-565, 1987.

11. Inafuku, S., Takimoto, I. and Inuzuka, I.: Inner ear changes due to the aging in normal mice. J. Aichi Med. Univ. Assoc. 10; 249-256, 1982. (in Japanese)

12. Kuroda, M.: Cochlear changes due to aging in normal mouse. J. Aichi Med. Univ. Assoc. 20; 657-672, 1992. (in Japanese)

13. Lefer, D. J., Scalia, R., Campbell, B., Nossuli, T., Hayward, R., Salamon, M., Grayson, J. and Lefer, A. M.: Peroxynitrite inhibits leukocyte-endothelial cell interactions and protects against ischemia-reperfusion injury in rats. J. Clin. Invest. 99; 684-691, 1997.

14. Markert, M., Carnal, B. and Mauel, J.: Nitric oxide production by activated human neutrophils exposed to sodium azide and hydroxylamine: the role of oxygen radicals. Biochem. Biophys. Res. Commun. 199; 1245-1249, 1994.

15. Marletta, M. A., Yoon, P.S., Iyenger, R., Leaf, C.D. and Wishnok, J. S.: Macrophage oxidation of $\mathrm{L}$-arginine to nitrite and nitrate: nitric oxide is an intermediate. Biochemistry 27; 8706-8711, 1988.

16. Morgan, J. M., Navabi, H., Schnid, K. W. and Jasani, B.: Possible role of tissue-bound calcium ions in citrate-mediated high-temperature antigen retrieval. J. Pathol. 174; 301-307, 1994.

17. Palmer, R. M. J., Ashton, D. S. and Moncada, S.: Vascular endothelial cells synthesize nitric oxide from L-arginine. Nature 333; 664-666, 1988.

18. Pierson, M. G. and Gray, B. H.: Superoxide dismutase activity in the cochlea. Hear. Res. 6; 141-151, 1982.

19. Sakuma, I., Stuehr, D. J., Gross, S. S., Nathan, C. and Levi, R.: Identification of arginine as a precursor of endotheliumderived relaxing factor. Proc. Natl. Acad. Sci. USA 85; 8664 $8667,1988$.

20. Schreck, R., Rieber, P. and Baeuerle, P. A.: Reactive oxygen intermediates as apparently widely used messengers in the activation of the NF- $\kappa \mathrm{B}$ transcription factor and HIV-1. EMBO J. $10 ; 2247-2258,1991$.

21. Takasaka, T.: Aging of the peripheral auditory system in the animal models. Otology Japan 1 (Suppl. 2); 129-149, 1991. (in Japanese)

22. Toda, N. and Okamura, T.: Possible role of nitric oxide in transmitting information from vasodilator nerve to cerebroarterial muscle. Biochem. Biophys. Res. Commun. 170; 308-313, 1990.

23. Tran, E. H., Hardin-Pouzet, H., Verge, G. and Owens, T.: Astrocytes and microglia express inducible nitric oxide synthase in mice with experimental allergic encephalomyelitis. $J$. Neuroimmunol. 74; 121-129, 1997.

24. Wink, D. A., Hanbauer, I., Krishna, M. C., DeGrafe, W., Gamson, J. and Mitchell, J. B.: Nitric oxide protects against cellular damage and cytotoxicity from reactive oxygen species. Proc. Natl. Acad. Sci. USA 90; 9813-9817, 1993.

25. Wu, M., Kimura, M., Inafuku, S. and Ishigami, H.: Effect of aging on the expression of iNOS and cell death in the mouse cochlear spiral ganglion. Okajima Folia Anat Jpn. 74; 155166, 1997.

26. Xie, Q. W. and Nathan, C.: The high-output nitric oxide pathway: role and regulation. J. Leukoc. Biol. 56; 576-582, 1994.

27. Xie, Q. W., Whisnant, R. and Nathan, C.: Promoter of the mouse gene encoding calcium-independent nitric oxide synthase confers inducibility by interferon gamma and bacterial lipopolysaccharide. J. Exp. Med. 177; 1779-1784, 1993. 